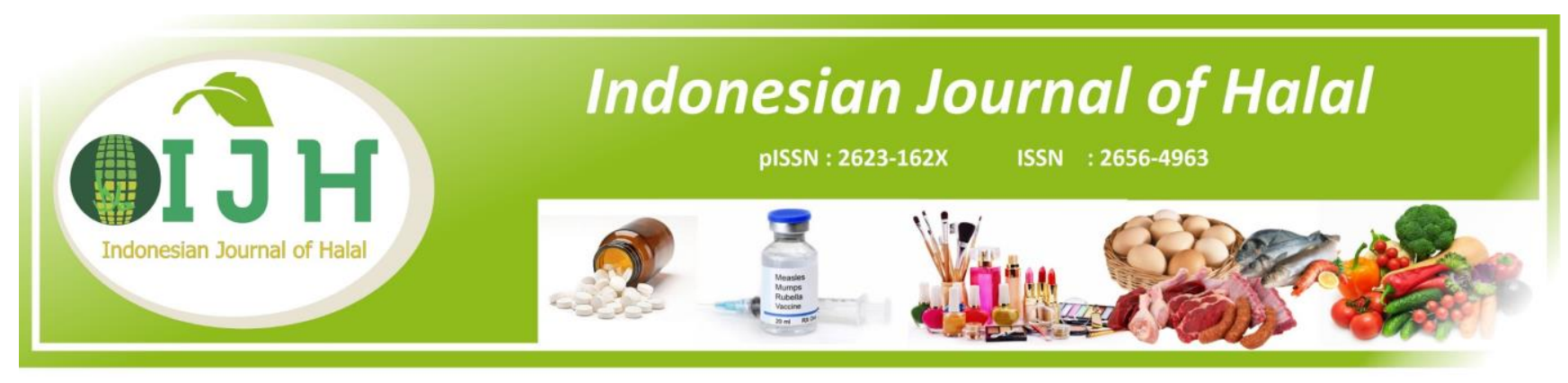

\title{
Analisis Kadar Etanol dalam Obat Batuk dengan Metode Kromatografi Cair
}

\author{
Arianti Nuur Annisa ${ }^{1 *}$, Handung Nuryadi' ${ }^{2}$, Widayat ${ }^{1)}$, Dita Ayu Sofiati ${ }^{1)}$ \\ J)Jurusan Teknik Kimia, Fakultas Teknik, Universitas Diponegoro \\ ${ }^{2)}$ Laboratorium Bioteknologi Laut Tropis, UPT LaboratoriumTerpadu, Universitas Diponegoro \\ *)Penulis korespondensi : ariantinuura@gmail.com
}

\begin{abstract}
ABSTRAK
Etanol merupakan senyawa kimia yang umum digunakan sebagai pelarut dalam obat-obatan. Keberadaan etanol dalam obat dapat diragukan kehalalannya. Diperlukan analisa kandungan etanol dalam suatu produk. Kromatografi cair merupakan metode yang akurat untuk mengetahui keberadaan etanol dalam sampel. Penelitian ini bertujuan untuk menganalisa kandungan etanol dalam obat batuk menggunakan metode HPLC. Metode yang dilakukan terdiri dari persiapan standar etanol dan sampel obat batuk, serta analisa sampel dengan HPLC. Data hasil analisa diolah dengan menggunakan software Lab Solutions. Selanjutnya disusun kurva analitik dan persamaan linear. Hasil analisa menunjukkan sampel obat batuk jenis XXX memiliki kandungan senyawa etanol. Dari hasil yang diperoleh dapat disimpulkan bahwa metode HPLC tepat digunakan untuk menentukan kehalalan suatu produk.
\end{abstract}

Kata kunci: Etanol, HPLC, Halal, Pelarut, Obat

\begin{abstract}
Analysis of Ethanol Levels in Cough Drugs with the Liquid Chromatography Method. Ethanol is a chemical compound commonly used as a solvent in medicine. The existence of ethanol in the drug can be doubted. An analysis of the ethanol content in a product is needed. Liquid chromatography is an accurate method to determine the presence of ethanol in the sample. This study aims to analyze the ethanol content in cough medicines using the HPLC method. The method carried out consisted of standard ethanol preparation and cough medicine samples, as well as analyzing samples with HPLC. Data analysis results are processed using Lab Solutions software. The analytic curves and linear equations were arranged. The results of the analysis showed the type of cough medicine XXX contained ethanol compounds. From the results obtained it can be concluded that the HPLC method is precisely used to determine the halalness of a product.
\end{abstract}

Keywords: Ethanol, HPLC, Halal, Solvent, Medicine

\section{PENDAHULUAN}

Etanol merupakan salah satu bahan kimia yang umum digunakan sebagai pelarut, diantaranya pada parfum, perasa, pewarna makanan dan obat-obatan. Senyawa ini bersifat mudah menguap dalam suhu kamar (Jhonprimen dkk, 2012). Namun produk obat dan makanan yang dalam proses pengolahannya menggunakan etanol masih diragukan kehalalannya. Penggunaan etanol dalam obat memiliki fungsi sebagai bahan berkhasiat, pelarut, pengawet dan perasa. Etanol sebagai bahan berkhasiat dalam obat pada umumnya hanya digunakan untuk penggunaan luar. Adapun etanol sebagai pelarut, pengawet dan perasa dapat tercampur secara homogen dan ikut terkonsumsi ke dalam tubuh (Mursyidi, 2002). Untuk mendukung pengembangan produk yang bermutu dan halal, perlu dilakukan analisa kandungan etanol dalam produk tersebut, terutama produk-produk yang dikonsumsi oleh manusia (makanan dan obat-obatan).

Obat batuk dan flu pada umumnya memiliki kandungan etanol. Senyawa etanol digunakan sebagai pelarut bahan aktif yang terdapat di dalamnya. Meskipun obat batuk yang digunakan berasal dari ramuan tradisional, dapat dimungkinkan memiliki kandungan etanol. Hal ini dikarenakan senyawa kimia yang memiliki aktivitas mukolitik lebih mudah larut dalam etanol. Sehingga pada umumnya digunakan etanol sebagai pelarut dalam proses ekstraksi senyawa kimia tersebut (Kurniati dkk, 2018). 
Analisa kandungan etanol dapat dilakukan menggunakan berbagai metode diantaranya kromatografi gas, kromatografi cair dan spektrometri. Adapun kromatografi cair dengn metode High Performance Liquid Chromatography (HPLC) paling akurat dan efisien untuk analisa kandungan etanol dalam produk. Ketidakpastian pengukuran dengan metode HPLC lebih kecil dibandingkan metode lainnya dengan standar deviasi 0,43 (Avila dkk, 2018). Pada HPLC keberadaan air tidak mengganggu proses analisa serta tidak menyebabkan kerusakan pada kolom dan mesin.

Dalam ajaran Islam diketahui bahwa etanol dikaitkan dengan khamr yang dinyatakan haram meskipun memiliki manfaat. Oleh karena itu tujuan penelitian ini adalah untuk melakukan analisa kadar etanol di dalam produk obat batuk menggunakan metode HPLC.

\section{METODE}

\section{Persiapan standar dan sampel}

Standar etanol yang digunakan berupa etanol PA yang dilarutkan dalam air distilasi dengan konsentrasi 1 hingga $40 \%$ dalam volume. Etanol diperoleh dari UPT Laboratorium Terpadu, Universitas Diponegoro yang disuplai oleh Merck. Lima buah sampel etanol dengan konsentrasi berbeda digunakan untuk membuat kurva kalibrasi. Sampel obat batuk jenis XXX diambil sejumlah $5 \mathrm{ml}$ untuk dianalisa kandungan etanol.

Sampel etanol dan obat batuk yang telah siap selanjutnya dilakukan filtrasi menggunakan membran acrodisc ukuran $0,45 \mu \mathrm{m}$. Filtrat yang diperoleh kemudian diinjeksikan sejumlah $1 \mathrm{ml}$ ke dalam vial gelas ukuran $1,5 \mathrm{ml}$ yang kemudian diletakkan ke dalam tray sampel HPLC. Selanjutnya sampel yang sudah siap, diinjeksikan untuk dilakukan analisa menggunakan HPLC.

\section{Analisa sampel dengan high performance liquid chromatography (HPLC)}

Seluruh sampel dianalisa menggunakan high performance liquid chromatography (HPLC) dengan RID-10A refractive index detector (Shimadzu) dan SIL20A autosampler (Shimadzu) di UPT Laboratorium Terpadu Universitas Diponegoro. Kolom yang digunakan yaitu YMC-Triart C8 ukuran $150 \mathrm{~mm}$ x 4,6 $\mathrm{mm}$, dengan ukuran partikel $5 \mu \mathrm{m}$. Fase gerak yang digunakan berupa air dan methanol dengan perbandingan $70 \% \mathrm{v} / \mathrm{v}: 30 \% \mathrm{v} / \mathrm{v}$ yang telah difiltrasi menggunakan membran cellulose nitrate dengan ukuran pori $0,45 \mu \mathrm{m}$ dan PTFE (polypropylene backed) ukuran pori $0,5 \mu \mathrm{m}$. Waktu analisa tiap sampel selama 10 menit dengan suhu kolom oven $40^{\circ} \mathrm{C}$, laju alir $1 \mathrm{ml} / \mathrm{menit}$ dan volume injeksi $10 \mu$ l. Selanjutnya dilakukan pengolahan data hasil analisa dengan menggunakan software Lab Solutions.

\section{HASIL DAN PEMBAHASAN}

\section{Analisa sampel}

Semua sampel yang telah dianalisa menggunakan HPLC memiliki profil kromatogram yang sama seperti yang ditampilkan pada Gambar 1. Peak etanol muncul pada menit ke 2,5.

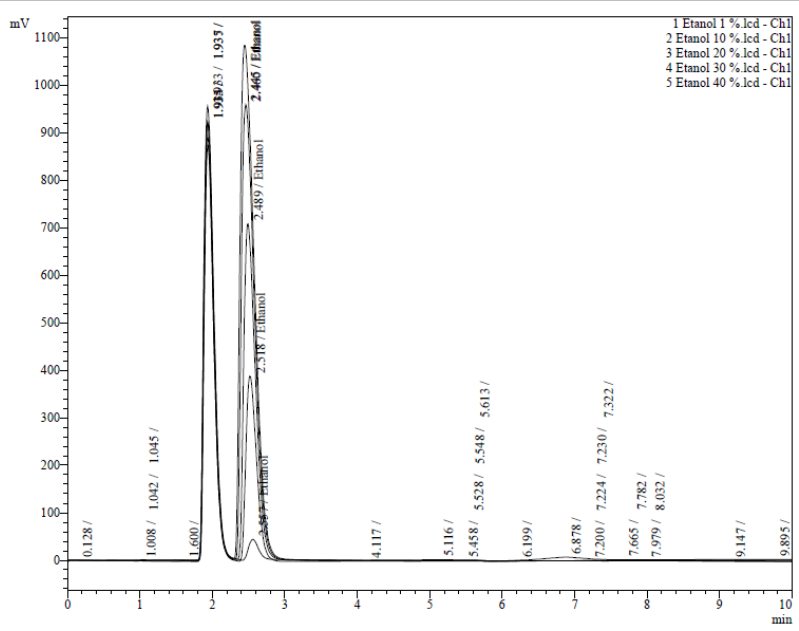

Gambar 1. Kromatogram HPLC sampel standar etanol konsentrasi $1-40 \%$ (volume)

\section{Validasi hasil}

Sampel standar etanol dengan serial konsentrasi $1 \%$ vol, $10 \%$ vol, $20 \%$ vol, $30 \%$ vol dan $40 \%$ vol diplotkan dalam software Lab Solutions untuk diperoleh kurva analitik. Kurva standar etanol menunjukkan korelasi linear dengan nilai regresi $\left(R^{2}\right)$ 0,996 dan persamaan $\mathrm{y}=0,383 \mathrm{x}+0,028$. Persamaan kurva standar yang diperoleh kemudian digunakan untuk menghitung konsentrasi etanol yang terkandung di dalam sampel obat batuk.

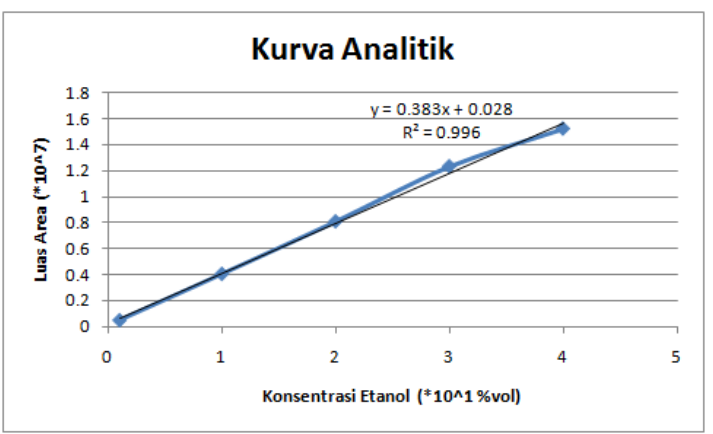

Gambar 2. Kurva analitik konsentrasi etanol

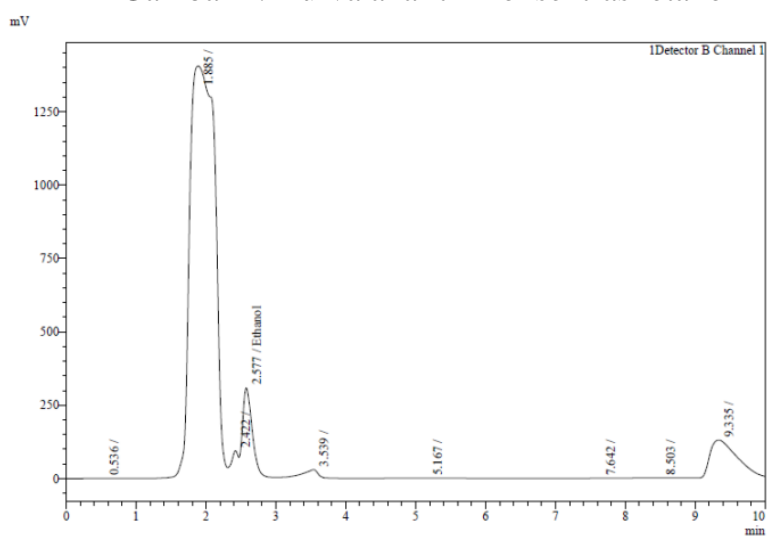

Gambar 3. Kromatogram HPLC sampel obat batuk

Dari Gambar 3 menunjukkan pada menit ke 2,5 muncul peak etanol. Persamaan yang diperoleh dari kurva analitik digunakan untuk menghitung konsentrasi etanol yang terkandung dalam sampel obat batuk. Hasil perhitungan menunjukkan bahwa sampel obat batuk jenis XXX memiliki kandungan etanol sebesar 7,339\%. 
Obat batuk jenis XXX dapat diragukan kehalalannya karena terdapat kandungan etanol sebesar $7,339 \%$. Meskipun konsentrasi etanol $<13 \%$, penggunaannya dalam obat batuk yang berfungsi sebagai pelarut pada umumnya berasal dari etanol dengan kadar $95 \%$ yang diperoleh dari proses distilasi hasil fermentasi (Mursyidi, 2002).

\section{KESIMPULAN}

Kromatografi cair merupakan metode yang efisien untuk menganalisa kandungan etanol dalam sampel. Dari hasil analisa menggunaka metode HPLC, diketahui bahwa sampel obat batuk jenis XXX diketahui memiliki kandungan etanol sebesar 7,339\%. Oleh karena itu metode ini tepat untuk menentukan halal dan haramnya suatu produk.

\section{DAFTAR PUSTAKA}

Jhonprimen, H. S., A. Turnip, M. H. Dahlan. 2012. Pengaruh Massa Ragi, Jenis Ragi dan Waktu Fermentasi pada Bioetanol dari Biji Durian. Jurnal Teknik Kimia 18(2): 43-51.

Mursyidi, A. 2002. Alkohol dalam Obat dan Kosmetika. Tarjih edisi ke 4.

Kurniati, N. F., D. W. Suwandi, S. Yuniati. 2018. Aktivitas Mukolitik Kombinasi Ekstrak Etanol Daun Kemangi dan Ekstrak Etanol Daun Sirih Merah. Pharmaceutical Sciences and Research 5(1): 7-13.

Avila, L. M., A. P. F. dos Santos, D. I. M. de Mattos, C. G. de Souza, D. F. de Andrade, L. A. d'Avila. 2018. Determination of ethanol in gasoline by highperformance liquid chromatography. Fuel 212: 236-239. 